\title{
Community respiration studies in saltern crystallizer ponds
}

\author{
Mareike Warkentin ${ }^{1}$, Rhena Schumann ${ }^{1}$, Aharon Oren ${ }^{2, *}$ \\ ${ }^{1}$ Department of Biological Sciences, Applied Ecology, University of Rostock, Albert-Einstein-Strasse 3, 18059 Rostock, \\ Germany \\ ${ }^{2}$ The Institute of Life Sciences, and the Moshe Shilo Minerva Center for Marine Biogeochemistry, The Hebrew University of \\ Jerusalem, Jerusalem, Israel
}

\begin{abstract}
To measure community respiration by the heterotrophic Archaea (dominated by Haloquadratum) and Bacteria (Salinibacter) in the NaCl-saturated crystallizer brines of the solar salterns in Eilat, Israel, and to obtain information on the substrates preferred by the community as energy sources, we used 2 complementary approaches: monitoring of changes in oxygen concentration using planar optode sensors in short (up to $30 \mathrm{~min}$ ) experiments, and long-term (up to 40-50 h) incubations using Winkler titration to assess changes in oxygen levels. Respiration rates measured were $\sim 3 \mathrm{fmol}$ cell $^{-1} \mathrm{~h}^{-1}$. Respiration was markedly stimulated by glycerol, dihydroxyacetone and pyruvate, but not by yeast extract, succinate, and fumarate. These findings are discussed in view of genomic information on the dominant heterotrophic organisms in the community as well as the outcome of earlier studies on the behavior of halophilic prokaryotes in situ and in laboratory cultures. Despite the low in situ respiration rate, the oxygen uptake studies added information on the activities of the heterotrophic communities in salt-saturated ecosystems and on the substrates metabolized by the microorganisms present.
\end{abstract}

KEY WORDS: Salterns · Respiration · Optodes $\cdot$ Glycerol $\cdot$ Dihydroxyacetone

\section{INTRODUCTION}

Saltern crystallizer ponds are an ideal system to study communities of halophilic microorganisms in their natural environment. Salterns are found worldwide in coastal tropical and subtropical areas; the nature of the microbial communities developing in the saturated brines from which $\mathrm{NaCl}$ precipitates as halite crystals is very similar irrespective of the geographical location: community densities are high, and the community structure is very simple (Javor 2002, Oren 2002a, 2009, this Special Issue). In saltern ponds with salt concentrations above 250 to $300 \mathrm{~g} \mathrm{l}^{-1}$, the only primary producer is generally the unicellular green alga Dunaliella salina, which is colored red-orange because of its high content of $\beta$-carotene. Dense communities of red halophilic Archaea (family Halobacteriaceae) are the main heterotrophic component in the brines, and they are generally present in numbers as high as $10^{7}$ to $10^{8}$ cells ml $\mathrm{m}^{-1}$ (Oren 1994, 2006). Most archaeal cells in salterns worldwide appear to belong to the flat square or rectangular, gas-vacuolated type first recognized by Walsby (1980), which was only recently brought into culture and described as Haloquadratum walsbyi (Burns et al. 2007). Other species of Halobacteriaceae are also present in crystallizer brines, but their quantitative contribution to the community is poorly understood (Oren 1994, 2002a,b). The contribution of extremely halophilic members of the phylum Bacteroidetes (Bacteria), which are also colored red, to the microbial communities in saltern crystallizer ponds was recognized only quite recently (Antón et al. 2000, Oren \& Rodríguez-Valera 2001, Oren 2002b). With the isolation of Salinibacter ruber (Antón et al. 2002), the most important organisms of the ecosystem are now available for study. 
While we possess a wealth of information about the community structure of the microbial communities in saltern crystallizer ponds and about the properties of the dominant members of the community, we know relatively little about the heterotrophic activity in such systems. Only occasionally have growth rates and metabolic activities within the community been estimated, based on e.g. leucine and thymidine incorporation (Pedrós-Alió et al. 2000, Oren 2002a,b). Hardly any information is available on the respiratory activity. We also know little about the substrates that contribute to the respiration of the heterotrophic community. Glycerol is often considered a key substrate, as it is produced in large amounts by the alga Dunaliella as osmotic stabilizer of the cytoplasm. Indeed, measurements of glycerol uptake and turnover in saltern crystallizers showed rapid uptake and turnover (Oren 1993, 1995a). On the other hand, pure culture studies with Haloquadratum and Salinibacter failed to confirm glycerol as a favored substrate (Antón et al. 2002, Burns et al. 2007). Microautoradiography studies in crystallizer brines from a Spanish saltern showed no significant incorporation of glycerol by the heterotrophic members of the community (Rosselló-Mora et al. 2003).

The high community density of halophilic Archaea and other extremely halophilic heterotrophic prokaryotes such as Salinibacter in saltern crystallizer ponds, which is 2 to 3 orders of magnitude higher than in most marine environments, should theoretically make this environment ideal for studies of heterotrophic activity, e.g. as measured by oxygen uptake. However, several problems are encountered. (1) With estimated in situ doubling times of up to $23 \mathrm{~d}$ (Oren 1994), a high community density does not necessarily imply high metabolic activity. (2) The solubility of oxygen in saturated brines is very limited (Sherwood et al. 1991, 1992); such brines are in fact nearly anaerobic, and oxygen detection systems should be sufficiently sensitive when working with such brines. We found one record of an earlier attempt to estimate respiratory oxygen consumption in near-salt-saturated saltern brines: incubation of brines (containing 250 to $280 \mathrm{~g} \mathrm{l}^{-1}$ salt and $6 \times 10^{7}$ to $7 \times 10^{7}$ prokaryotic cells $\mathrm{ml}^{-1}$ ) from the Bras del Port salterns near Alicante, Spain, for $4 \mathrm{~h}$ under in situ conditions in BOD bottles, followed by Winkler oxygen titration, gave respiration rates below $0.3 \mu \mathrm{mol} \mathrm{O} \mathrm{l}^{-1} \mathrm{~h}^{-1}$ (Pedrós-Alió et al. 2000).

Here, we present respiration studies of the heterotrophic prokaryotic community of the saltern crystallizer ponds in Eilat, Israel, using 2 complementary approaches: continuous monitoring of changes in oxygen concentration using (1) planar optode sensors and (2) long-term (up to 40-50 h) incubations, using the classic Winkler titration to assess changes in oxygen levels.
Using both approaches, we tested the effect of different organic compounds on community respiration rates to obtain information on the substrates preferred by the community as energy sources for respiration.

\section{MATERIALS AND METHODS}

Saltern brine samples. Brine was collected from ponds 304 and 307 of the salterns of the Israel Salt Company in Eilat in April 2008 (Table 1; see Prášil et al. 2009, this Special Issue, for a map of the ponds showing the sampling sites). The density of the brines was measured using a hydrometer, and converted to salinity using a calibration curve based on the weight of the salt remaining after drying $1 \mathrm{ml}$ volumes overnight at $200^{\circ} \mathrm{C}$. Prokaryotic cells were enumerated with a Petroff-Hauser counting chamber using a microscope equipped with phase-contrast optics, after 5 to 10 -fold concentration by centrifugation (20 min, $12000 \times$ g) (Oren et al. 1995, Oren \& Rodríguez-Valera, 2001). Dunaliella cells were counted by filtering brine samples $(2.5 \mathrm{ml})$ through Millipore filters $(25 \mathrm{~mm}$ diameter, $5 \mu \mathrm{m}$ mean pore size) and counting cells on the filter. Cell numbers were calculated from the average cell number per field and the field diameter (Oren 1993). The relative accuracy of the algal and prokaryotic cell counts was estimated at \pm 10 and $20 \%$, respectively.

Oxygen uptake experiments using planar optode sensors. Prokaryotic cells from the saltern brine collected on April 1, 2008 (Table 1) were concentrated by centrifugation under mild conditions $(1500 \times g$, 35 min, $20^{\circ} \mathrm{C}$ ) and suspended in the original brine or in brine diluted with $20 \%(\mathrm{v} / \mathrm{v})$ distilled water (total salt concentration of $263 \mathrm{~g} \mathrm{l}^{-1}$ ) to a final density of $7.9 \times 10^{8}$ and $6.3 \times 10^{8} \mathrm{cells} \mathrm{ml}^{-1}$, respectively. Dunaliella cells, being lighter than the brine, floated during centrifugation, and were not collected in the cell pellet. Subsamples $(3.5 \mathrm{ml})$ of the cell concentrate were placed in an airtight, closed cuvette with an optical oxygen sensor spot (SP-PSt3-YOP-PSUP-D5) connected to a Fibox 3 device (PreSens) (Warkentin et al. 2007). Samples were equilibrated for $20 \mathrm{~min}$ at $35^{\circ} \mathrm{C}$ in a thermostatcontrolled water bath (Heto Chill Master Comfort CB830E). Different carbon sources (glycerol, dihydroxyacetone, Na-pyruvate, Na-succinate and $\mathrm{NaOH}-$ neutralized fumaric acid) were added from concentrated stock solutions to a final concentration of $1 \mathrm{mM}$, and respiration activity was then measured in the dark for at least $30 \mathrm{~min}$ at $35^{\circ} \mathrm{C}$.

The PreSens system was calibrated with a 2-point calibration. First, 0\% oxygen saturation was defined by adding sodium dithionite to distilled water. Then, distilled water was aerated for 20 min with ambient air, 
stirred for another 20 min to avoid oversaturation, and used to calibrate the $100 \%$ oxygen saturation. Respiration data were expressed as a decrease in oxygen saturation, $100 \%$ being the physical saturation of distilled water at the given temperature, or were converted to oxygen concentrations. It was not possible to directly convert the optode readings to oxygen concentrations in $\mu \mathrm{M}$, as the matrix behind the optode did not give reliable values at salt concentrations above that of seawater. The principle of the mathematical optode matrix is based on the conversion (by a software) of angular dimension (phase in ${ }^{\circ}$ ) into oxygen saturation and concentration. The phase describes the temporal distance of an oscillation from its 0 point. High phase values (in this case, $55.82^{\circ}$ ) are reached when no oxygen is available and, hence, the fluorescence signal would not be quenched by oxygen. Otherwise, oxygen saturated water quenches the fluorescence signal down to a phase of $26.33^{\circ}$. Because the conversion of optode readings could not be calculated directly, we extrapolated the values against oxygen concentrations at different salinities ( 0 to $358 \mathrm{~g} \mathrm{l}^{-1} \mathrm{NaCl}$ ) as given by Sherwood et al. (1992). The mathematical function of oxygen concentration that depends on the increasing salinity provided oxygen concentrations of $39 \mu \mathrm{mol} \mathrm{l}^{-1}$ at $263 \mathrm{~g} \mathrm{l}^{-1} \mathrm{NaCl}$ and $16 \mathrm{mmol} \mathrm{l}^{-1}$ at $329 \mathrm{~g} \mathrm{l}^{-1} \mathrm{NaCl}$, at which conditions experiments were carried out (Fig. 1). The resulting extrapolated oxygen concentrations were related to the $100 \%$ saturated calibration of the optode. Furthermore, a nonlinear decrease in oxygen concentration occurred in the first 10 to $15 \mathrm{~min}$ of measurement in several samples. This was attributed to insufficient temperature equilibration of the samples or the inertia of the spot membrane. Therefore, the initial time interval was excluded from the calculations when such a nonlinear decrease was observed (cf. Warkentin et al. 2007).

Measurement of oxygen uptake in BOD bottles, using Winkler titration. Another strategy to follow oxygen uptake in brine samples in the presence of different organic substrates was incubating the samples in $50 \mathrm{ml}$ glass stoppered BOD bottles, and then measuring the oxygen concentrations in the brine after different periods of incubation using the Winkler oxygen titration. Bottles were completely filled with saltern brine within $1 \mathrm{~h}$ of sampling using a hose, taking care

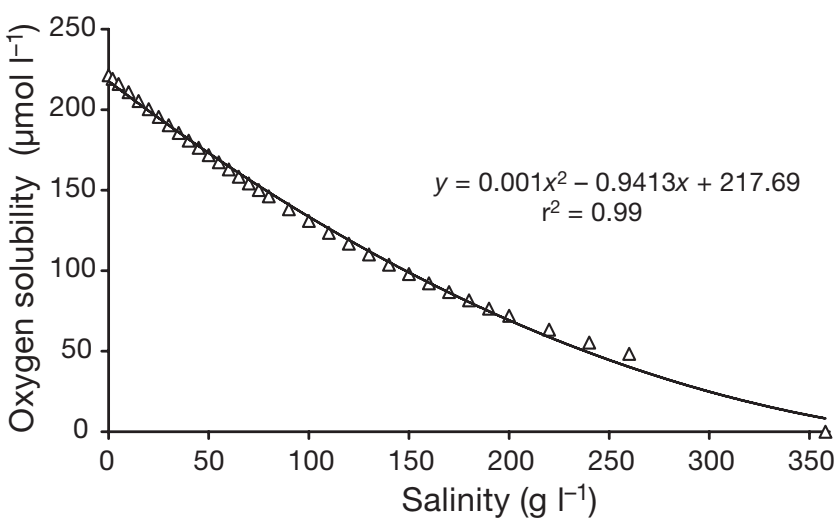

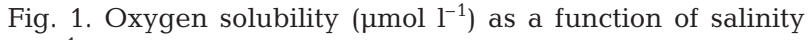
$\left(\mathrm{g} \mathrm{l}^{-1}\right.$ ) at $35^{\circ} \mathrm{C}$ (based on data from Sherwood et al. 1992)

not to introduce air bubbles. For each time point, triplicate bottles were filled, and carbon sources were added as follows: glycerol, dihydroxyacetone, Napyruvate, Na-succinate and $\mathrm{NaOH}$-neutralized fumaric acid to a final concentration of $1 \mathrm{mM}$, and yeast extract and peptone (Oxoid) to $10 \mathrm{mg} \mathrm{l}^{-1}$. At time 0 and after different periods of incubation in the dark at $30^{\circ} \mathrm{C}$ (3 to 4 time points, with incubation up to 40-50 h), the oxygen concentration remaining in the bottles was assayed using Winkler titration. Oxygen was fixed by the addition of $0.5 \mathrm{ml}$ of $36.5 \%$ $\mathrm{MnSO}_{4} \cdot \mathrm{H}_{2} \mathrm{O}$ and $0.5 \mathrm{ml}$ of $28.5 \% \mathrm{KI}$ solution $+47.5 \%$ $\mathrm{NaOH}$. After at least $2 \mathrm{~h}$ incubation at room temperature, $1 \mathrm{ml}$ of concentrated $\mathrm{H}_{2} \mathrm{SO}_{4}$ was added, and the iodine liberated was titrated with $0.1 \mathrm{M} \mathrm{Na}_{2} \mathrm{~S}_{2} \mathrm{O}_{3}$ by means of an automatic burette (Metrohm, Dosimat 775), using starch as indicator.

\section{RESULTS}

Microscopic examination of the brine samples collected from the Eilat salterns showed the presence of dense communities of prokaryotes (Table 1), with flat square Haloquadratum-type cells representing 60 to $70 \%$ of the cell numbers, as reported in the past (Oren et al. 1995, Oren 2002a).

The brine sample was between 93 and $94 \%$ oxygen saturated. To increase the sensitivity of the oxygen uptake experiments using the optode oxygen sensor

Table 1. Brine samples used and their properties. Data for Dunaliella salina and prokaryotic cells are means \pm SD

\begin{tabular}{|lcccccc|}
\hline Date & Pond no. & $\begin{array}{c}\text { Density } \\
\left(\mathrm{g} \mathrm{ml}^{-1}\right)\end{array}$ & $\begin{array}{c}\text { Total dissolved } \\
\text { salts }\left(\mathrm{g} \mathrm{l}^{-1}\right)\end{array}$ & $\begin{array}{c}\text { Temperature } \\
\left({ }^{\circ} \mathrm{C}, \text { noon }\right)\end{array}$ & $\begin{array}{c}\text { Dunaliella salina } \\
\text { cells ml }^{-1}\end{array}$ & $\begin{array}{c}\text { Prokaryotic } \\
\text { cells ml }^{-1}\end{array}$ \\
\hline April 1, 2008 & 304 & 1.215 & 329 & 24 & $110 \pm 10$ & $3.3 \pm 0.3 \times 10^{7}$ \\
April 27, 2008 & 307 & 1.233 & 355 & 30 & $280 \pm 20$ & $3.9 \pm 0.4 \times 10^{7}$ \\
\hline
\end{tabular}


and to shorten the time of each rate determination, we concentrated the cells 24 -fold by low-speed centrifugation. This yielded a cell preparation that gave a decrease in oxygen saturation level of $\sim 1 \%$ in $10 \mathrm{~min}$ (Fig. 2). This rate, albeit low, is still in the range that can be reliably detected with the sensor system used. Dilution of the brine containing the cell concentrate with $20 \%$ distilled water resulted in an increase in the oxygen uptake rate (Fig. 2).

We then used the diluted brine sample (80\% saltern brine, $20 \%$ distilled water, cell count $6.3 \times 10^{8} \mathrm{ml}^{-1}$ ) to test the effect of different organic substrates on community respiration. Addition of $1 \mathrm{mM}$ glycerol, dihydroxyacetone and pyruvate yielded oxygen uptake rates of 2.8, 2.9 and $2.1 \mu \mathrm{mol} \mathrm{l^{-1 }} \mathrm{h}^{-1}$, respectively, compared to $1.7 \mu \mathrm{mol} \mathrm{l} \mathrm{l}^{-1} \mathrm{~h}^{-1}$ without added substrate (Fig. 3). Cellspecific respiration rates varied between 3.3 and $4.6 \mathrm{fmol} \mathrm{cell}^{-1} \mathrm{~h}^{-1}$ after substrate stimulation compared to $2.7 \mathrm{fmol} \mathrm{cell}^{-1} \mathrm{~h}^{-1}$ without substrate addition.

Measurements of oxygen uptake in BOD bottles, using Winkler titration to assess the oxygen concentration after different incubation periods, required longer incubation times; however, the method could be used in the brine without the need for a centrifugation step to concentrate the cells - which could possibly damage the cells, including damage to Dunaliella that potentially leads to a release of glycerol to the medium - or dilution to stimulate heterotrophic activity. The oxygen concentration at the time of sampling was $\sim 25 \mu \mathrm{mol} \mathrm{l}^{-1}$, which is close to the value expected for such saturated brines (Sherwood et al. 1991, 1992). In the absence of added substrate, the oxygen concentration decreased to $\sim 0.5$ of the initial value after $24 \mathrm{~h}$ incubation in the dark at $30^{\circ} \mathrm{C}$ (Fig. 4). While the respiration rates measured in the independent experiments showed some variability (up to $20-40 \%$ ), as shown by the SD bars in Fig. 5, stimulation of the activity by glycerol, dihydroxyacetone and pyruvate was confirmed in

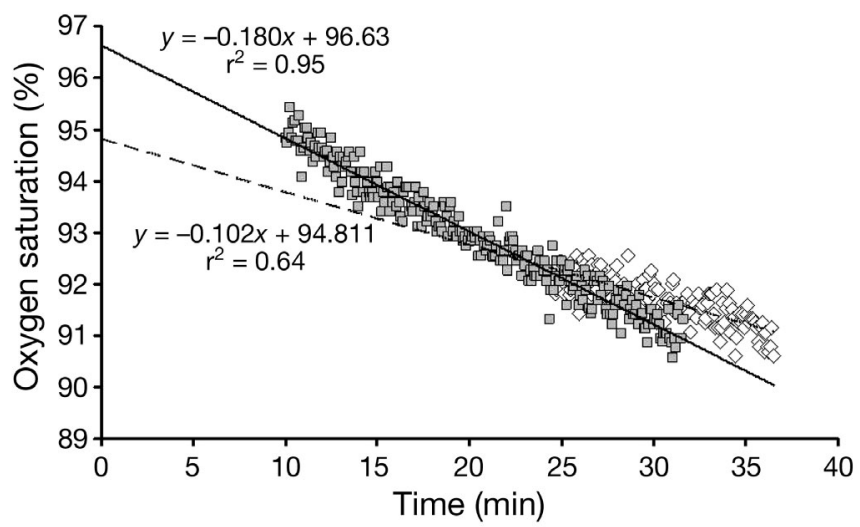

Fig. 2. Stimulation of heterotrophic respiration activity ( $\%$ oxygen saturation) without $\left(\diamond_{;}----\right)$and after addition of $20 \%$ distilled water $(\square ;-)$, measured at $35^{\circ} \mathrm{C}$
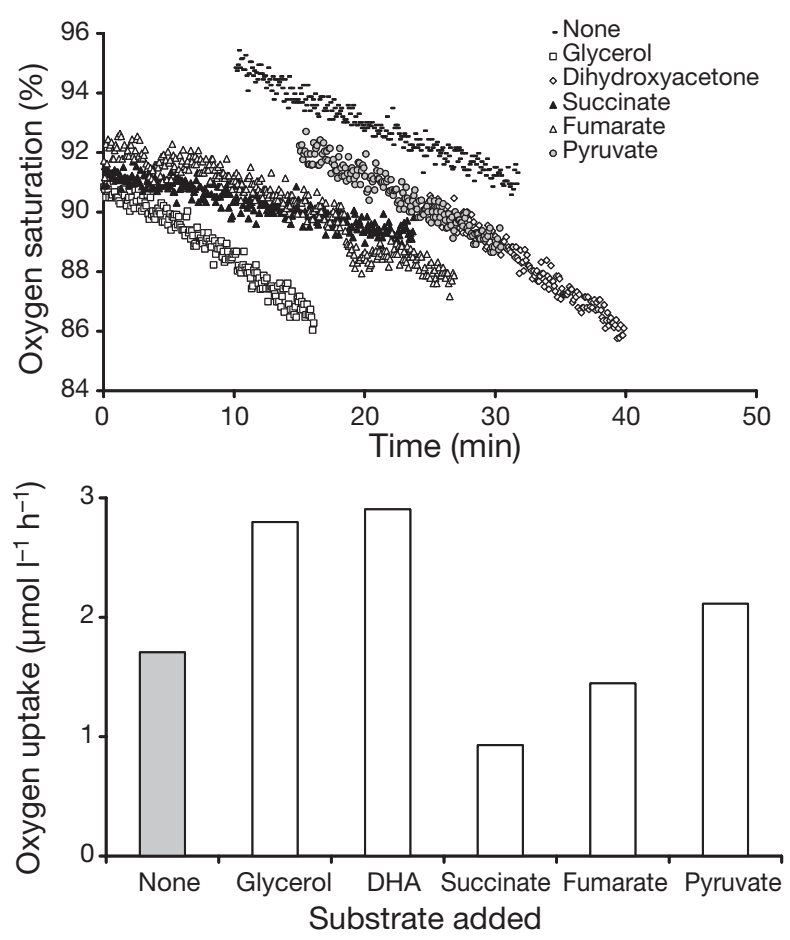

Fig. 3. Oxygen uptake by a halophilic bacterial community $\left(6.3 \times 10^{8}\right.$ cells ml $\left.{ }^{-1}\right)$ suspended in $20 \%$ diluted brine of pond 304 , measured at $35^{\circ} \mathrm{C}$ and expressed as a decrease in oxygen saturation $\left(\% \mathrm{~h}^{-1}\right)$ after addition of glycerol $(\square)$, dihydroxyacetone $(\diamond)$, succinate $(\boldsymbol{\Delta})$, fumarate $(\Delta)$, and pyruvate $(\bullet)$ (all at $1 \mathrm{mM}$ ) as compared to (a) a control experiment without added organic substrate (-) and (b) calculated respiration rates $\left(\mu \mathrm{mol} \mathrm{O} \mathrm{O}^{-1} \mathrm{~h}^{-1}\right)$

these experiments. Peptone also stimulated oxygen uptake. No stimulatory effect by yeast extract and by succinate was found. Fumarate (a substrate tested in only one experiment) caused a slight decrease in community respiration (Fig. 5).

\section{DISCUSSION}

The very low solubility of oxygen in saturated brines (Sherwood et al. 1991, 1992) and the correspondingly low oxygen concentrations that have been reported for saltern crystallizer ponds (Oren 2009) have probably discouraged studies of oxygen respiration by the heterotrophic communities in such brines. The present work is therefore one of the first studies to measure kinetics of oxygen uptake under different conditions to obtain information on the activities of the community of extremely halophilic prokaryotes.

Two approaches were used to measure oxygen in the brine: planar oxygen optodes and Winkler titration. In both cases, we worked near the lower sensitivity of each 


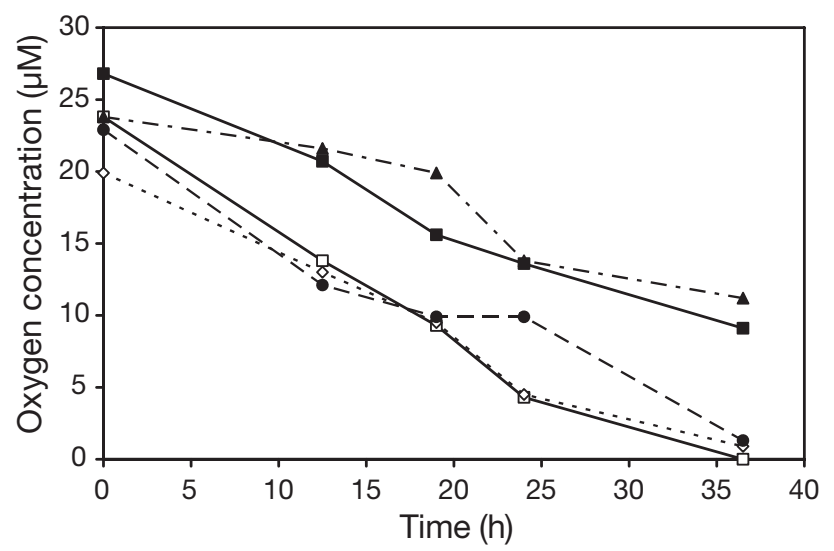

Fig. 4. Oxygen consumption in BOD bottles filled with water from pond 307 (April 27, 2008; $3.9 \times 10^{7}$ prokaryotic cells ml ${ }^{-1}$ ) and incubated in the dark at $30^{\circ} \mathrm{C}$ without added substrate $(\boldsymbol{\square})$ and with $1 \mathrm{mM}$ Na-succinate $(\boldsymbol{\Delta})$, glycerol $(\square)$, Napyruvate $(\bullet)$, and dihydroxyacetone $(\diamond)$. Data points are the average of 3 independent determinations, variations generally being $\pm 2 \mu \mathrm{M}$

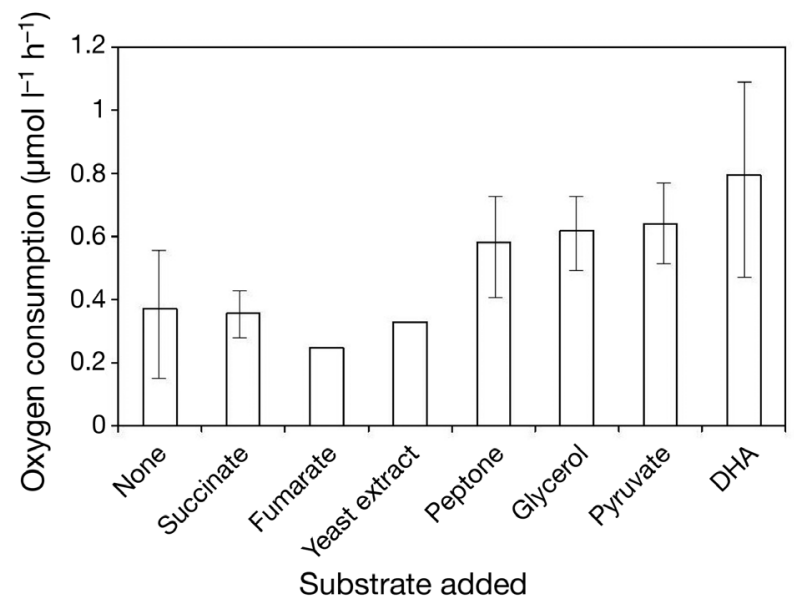

Fig. 5. Average oxygen consumption rate $( \pm S D)$ in the presence of different carbon sources calculated from 1 (fumarate, yeast extract), 2 (peptone) or 3 (glycerol, pyruvate, dihydroxyacetone) independent experiments similar to the one presented in Fig. 3

method, which required some special modifications of the standard methods. For the optode studies, cells had to be concentrated by centrifugation, introducing potential artefacts due to possible damage of the cells. The chemical oxygen assay by Winkler titration worked well, although different modifications of the standard method have been recommended for use in hypersaline solutions (Javor 2002, Oren 2009). However, to obtain significant decreases in oxygen concentration, long incubation times were needed, which could possibly affect the microbial community and introduce errors. An earlier attempt to measure respiration in Spanish saltern ponds using dark BOD bottles incubated in situ for $2 \mathrm{~h}$ did not yield measurable oxygen uptake rates at the highest salinities (Pedrós-Alió et al. 2000).
Dilution of the brine with $20 \%$ distilled water stimulated oxygen uptake rates (Fig. 2). This suggests that the salinity of the saltern crystallizer brines exceeds the optimal values for those microorganisms best adapted to life in extremely high salt concentrations. Similarly, when a suspension of Haloquadratum cells from the Eilat saltern brine was diluted with $20 \%$ distilled water, a similar 3-fold stimulation of heterotrophic activity (incorporation of radiolabeled amino acids) was found (Elevi Bardavid \& Oren 2008a).

For a proper evaluation of the results of the substrate addition experiments (Figs. 3 \& 5), an understanding of the microbial community structure and the properties of the dominant species is essential. Fortunately, the diversity of heterotrophic microorganisms in saltern crystallizer ponds worldwide is low: Archaea of the family Halobacteriaceae, and especially of the genus Haloquadratum, make up the majority of the prokaryotes, with a minor contribution of other species of the family and of Salinibacter (Bacteroidetes) (Oren $2002 a, b)$. The contribution of such extremely halophilic members of the Bacteria to the community has been recognized only recently (Antón et al. 2000, 2002). In the Eilat salterns, Salinibacter may be less abundant than in salterns in Spain (Oren \& RodríguezValera 2001), but its presence could still be ascertained using both culture-dependent techniques (Elevi Bardavid et al. 2007) and culture-independent methods such as fluorescence in situ hybridization: in samples collected between August 2006 and April 2007, 13 to $23 \%$ of the cells hybridized with a probe for the Salinibacter group, while 76 to $84 \%$ reacted with an archaeal probe (Elevi Bardavid 2008). In the samples used in the present study, the relative contribution of Salinibacter was not determined, but microscopically, the square flat Archaea were dominant. As it was also found that the activity per cell of Haloquadratum walsbyi suspended in the Eilat crystallizer brine was more than an order of magnitude higher than that of Salinibacter ruber, at least as assessed by amino acid incorporation rate (Elevi Bardavid \& Oren 2008a), most of the respiratory activity measured was probably due to the archaeal component of the community.

Glycerol, which is produced as an osmotic solute by the alga Dunaliella in saltern crystallizer ponds, is often considered as a key substrate for the heterotrophic community in these ponds (Oren 2002b, Elevi Bardavid et al. 2008). Many members of the Halobacteriaceae grow well on glycerol (Oren 1994, 2002a). Studies of radiolabeled glycerol showed high uptake rates and short glycerol turnover times in salt-saturated saltern ponds (Oren 1993). In a study in which respiratory electron transport in the Eilat saltern crystallizer ponds was estimated according to the rate of reduction of INT [2-(p-iodophenyl)-3-( $p$-nitrophenyl)- 
5-phenyltetrazolium chloride], addition of glycerol stimulated the rate by $52 \%$ (Oren 1995a), which is similar to the stimulation found in our oxygen respiration studies (Figs. 3 \& 5). It is interesting to note that previously reported INT reduction rates are equal to the oxygen uptake rates found in the present study. The rate of $372 \mathrm{nmol}$ INT reduced $\mathrm{l}^{-1} \mathrm{~h}^{-1}$ in brine containing $2.1 \times 10^{7}$ cells ml $^{-1}$ (Oren 1995a) is nearly identical to the $370 \mathrm{nmol} \mathrm{O}_{2} \mathrm{l}^{-1} \mathrm{~h}^{-1}$ in brine with $3.9 \times 10^{7}$ cells ml $^{-1}$ (Fig. 5), taking into account that INT reduction is a 2electron process and $\mathrm{O}_{2}$ reduction involves 4 electrons. In the INT reduction studies, stimulation of respiratory activity was also obtained with casamino acids (44\%), D-lactate $(35 \%)$, yeast extract $(17 \%)$, and pyruvate $(9 \%)$, while acetate, succinate and glucose had little or no effect (Oren 1995a).

The genome of Haloquadratum walsbyi and the metagenome of the Haloquadratum community in Spanish salterns contain all the genes necessary for the efficient use of glycerol as substrate for growth (Bolhuis et al. 2006, Legault et al. 2006). However, the extent to which this property is indeed expressed is far from clear. The species description states that the best growth substrate is pyruvate, and that no growth enhancement was observed with acetate, fumarate, glycerol, succinate and a number of other simple compounds (Burns et al. 2007). Microautoradiography studies combined with fluorescence in situ hybridization did not show significant incorporation of glycerol into the square Archaea that dominated the community in Spanish crystallizer ponds either (RossellóMora et al. 2003). However, the significance of this finding is not very clear, as incorporation of amino acids - one of the favorite substrates of Haloquadratum-was also negative in that study. There is also some confusion about the ability of Salinibacter to use glycerol. The above-cited microautoradiography study failed to show incorporation of glycerol into Salinibacter cells in the saltern community (Rosselló-Mora et al. 2003), and the species description of Salinibacter ruber states that glycerol does not stimulate growth (Antón et al. 2002). However, later studies have demonstrated that glycerol is metabolized by Salinibacter: part of the substrate is respired as $\mathrm{CO}_{2}$, part is incorporated into cell material (Sher et al. 2004), and part is incompletely oxidized to a soluble product, which was later identified as dihydroxyacetone (Elevi Bardavid \& Oren 2008b). The discrepancies between the results obtained in these different studies may well be due to the different methodologies used and the different incubation periods involved.

The potential importance of dihydroxyacetone in community metabolism in hypersaline environments such as saltern ponds was first suggested from the analysis of the genome of Haloquadratum walsbyi
(Bolhuis et al. 2006). It was subsequently ascertained that the product of incomplete oxidation of glycerol by Salinibacter is dihydroxyacetone and that dihydroxyacetone is indeed efficiently used by Haloquadratum cultures as well as by the microbial community of the saltern crystallizer ponds of Eilat (Elevi Bardavid \& Oren 2008b, Elevi Bardavid et al. 2008). Considering these data, it is not surprising that dihydroxyacetone stimulated oxygen respiration by the community (Figs. 3 \& 5). Another substrate that increased oxygen uptake was pyruvate. Pyruvate was reported to be produced by incomplete oxidation of glycerol and sugars by some halophilic Archaea, together with D-lactate and acetate (Oren \& Gurevich 1994). D-lactate is rapidly metabolized by the community (Oren \& Gurevich 1994, Oren 1995a), but acetate metabolism is very slow (Oren 1995b). Pyruvate is also the best growth substrate for Haloquadratum (Burns et al. 2007).

Fumarate was included in our study for a different reason: some members of the Halobacteriaceae can grow anaerobically by fumarate reduction, and fumarate can therefore serve as an alternate electron acceptor (Oren 1991). If key members of the heterotrophic community in the saltern ponds can indeed shift from aerobic respiration to fumarate reduction, addition of fumarate may have a sparing effect on oxygen respiration. In the present study, fumarate slightly decreased oxygen uptake, but as the result has not been confirmed in repeated experiments, no conclusions can yet be drawn. During the characterization of the species Haloquadratum walsbyi and Salinibacter ruber, the ability to grow anaerobically on fumarate has not been tested (Antón et al. 2002, Burns et al. 2007), and no genes have been annotated as fumarate reductase in the genomes of these prokaryotes (Mongodin et al. 2005, Bolhuis et al. 2006).

The results presented here show that valuable information on the heterotrophic communities in saltsaturated ecosystems can be gained from oxygen uptake studies.

Acknowledgements. We thank the Israel Salt Company in Eilat for allowing access to the salterns, and S. Forster for help in calibrating and converting the common oxygen measurement methods against the oxygen sensor spots under the difficult hypersaline conditions. Funding was provided by the Israel Science Foundation (grant no. 617/07 to A.O.) and the Deutsche Forschungsgemeinschaft (Schu 965/7-1, Wa 2723/1-1). We also thank the Batsheva de Rothschild Foundation, Bar Ilan University, the Moshe Shilo Center for Marine Biogeochemistry, and the staff of the Interuniversity Institute for funding and logistic support. This study was partly done during the 8th International Workshop of the Group for Aquatic Primary Productivity (GAP) and the Batsheva de Rothschild Seminar on Gross and Net Primary Productivity held at the Interuniversity Institute for Marine Sciences, Eilat, Israel in April 2008. 


\section{LITERATURE CITED}

Antón J, Rosselló-Mora R, Rodríguez-Valera F, Amann R (2000) Extremely halophilic Bacteria in crystallizer ponds from solar salterns. Appl Environ Microbiol 66:3052-3057

Antón J, Oren A, Benlloch S, Rodríguez-Valera F, Amann R, Rosselló-Mora R (2002) Salinibacter ruber gen. nov., sp. nov., a novel extreme halophilic member of the Bacteria from saltern crystallizer ponds. Int J Syst Evol Microbiol 52:485-491

Bolhuis H, Palm P, Wende A, Farb M and others (2006) The genome of the square archaeon Haloquadratum walsbyi: life at the limits of water activity. BMC Genomics 7:169

Burns DG, Janssen PH, Itoh T, Kamekura M and others (2007) Haloquadratum walsbyi gen. nov., sp. nov., the square haloarchaeon of Walsby, isolated from saltern crystallizers in Australia and Spain. Int J Syst Evol Microbiol 57: 387-392

Elevi Bardavid R (2008) The ecological role of the extremely halophilic bacterium Salinibacter ruber in saltern crystallizer ponds. $\mathrm{PhD}$ thesis, the Hebrew University of Jerusalem

- Elevi Bardavid R, Oren A (2008a) Sensitivity of Haloquadratum and Salinibacter to antibiotics and other inhibitors: implications for the assessment of the contribution of Archaea and Bacteria to heterotrophic activities in hypersaline environments. FEMS Microbiol Ecol 63:309-315

Elevi Bardavid R, Oren A (2008b) Dihydroxyacetone metabolism in Salinibacter ruber and in Haloquadratum walsbyi. Extremophiles 12:125-131

Elevi Bardavid R, Ionescu D, Oren A, Rainey FA and others (2007) Selective enrichment, isolation and molecular detection of Salinibacter and related extremely halophilic Bacteria from hypersaline environments. Hydrobiologia 576:3-13

Elevi Bardavid R, Khristo P, Oren A (2008) Interrelationships between Dunaliella and halophilic prokaryotes in saltern crystallizer ponds. Extremophiles 12:5-15

> Javor BJ (2002) Industrial microbiology of solar salt production. J Ind Microbiol Biotechnol 28:42-47

Legault BA, Lopez-Lopez A, Alba-Casado JC, Doolittle WF, Bolhuis H, Rodríguez-Valera F, Papke RT (2006) Environmental genomics of Haloquadratum walsbyi in a saltern crystallizer indicates a large pool of accessory genes in an otherwise coherent species. BMC Genomics 7:171

> Mongodin EF, Nelson KE, Daugherty S, DeBoy RT and others (2005) The genome of Salinibacter ruber: convergence and gene exchange among hyperhalophilic Bacteria and Archaea. Proc Natl Acad Sci USA 102:18147-18152

Oren A (1991) Anaerobic growth of halophilic Archaeobacteria by reduction of fumarate. J Gen Microbiol 137: $1387-1390$

> Oren A (1993) Availability, uptake, and turnover of glycerol in hypersaline environments. FEMS Microbiol Ecol 12:15-23

Oren A (1994) The ecology of extremely halophilic Archaea. FEMS Microbiol Rev 13:415-440

Editorial responsibility: Ilanan Berman-Frank, Ramat Gan, Israel
Oren A (1995a) The role of glycerol in the nutrition of halophilic archaeal communities: a study of respiratory electron transport. FEMS Microbiol Ecol 16:281-290

> Oren A (1995b) Uptake and turnover of acetate in hypersaline environments. FEMS Microbiol Ecol 18:75-84

Oren A (2002a) Halophilic microorganisms and their environments. Kluwer Scientific Publishers, Dordrecht

Oren A (2002b) Molecular ecology of extremely halophilic Archaea and Bacteria. FEMS Microbiol Ecol 39:1-7

Oren A (2006) The order Halobacteriales. In: Dworkin M, Falkow S, Rosenberg E, Schleifer K-H, Stackebrandt E (eds) The prokaryotes. A handbook on the biology of bacteria: ecophysiology and biochemistry, Vol 3. Springer, New York, p 113-164

$>$ Oren A (2009) Saltern evaporation ponds as model systems for the study of primary production processes under hypersaline conditions. Aquat Microb Ecol 56:193-204

Oren A, Gurevich P (1994) Production of D-lactate, acetate, and pyruvate from glycerol in communties of halophilic Archaea in the Dead Sea and in saltern crystallizer ponds. FEMS Microbiol Ecol 14:147-156

> Oren A, Rodríguez-Valera F (2001) The contribution of Salinibacter species to the red coloration of saltern crystallizer ponds. FEMS Microbiol Ecol 36:123-130

Oren A, Duker S, Ritter S (1996) The polar lipid composition of Walsby's square bacterium. FEMS Microbiol Lett 138:135-140

Pedrós-Alió C, Calderón-Paz JI, MacLean MH, Medina G, Marrasé C, Gasol JM, Guixa-Boixereu N (2000) The microbial food web along salinity gradients. FEMS Microbiol Ecol 32:143-155

Prášil O, Bína D, Medová H, Řeháková K, Zapomělová E, Veselá J, Oren A (2009) Emission spectroscopy and kinetic fluorometry studies of phototrophic microbial communities along a salinity gradient in solar saltern evaporation ponds of Eilat, Israel. Aquat Microb Ecol 56: 285-296

- Rosselló-Mora R, Lee N, Antón J, Wagner M (2003) Substrate uptake in extremely halophilic microbial communities revealed by microautoradiography and fluorescence in situ hybridization. Extremophiles 7:409-413

Sher J, Elevi R, Mana L, Oren A (2004) Glycerol metabolism in the extremely halophilic bacterium Salinibacter ruber. FEMS Microbiol Lett 232:211-215

Sherwood JR, Stagnitti F, Kokkinn MJ, Williams WD (1991) Dissolved oxygen concentrations in hypersaline waters. Limnol Oceanogr 36:235-250

> Sherwood JR, Stagnitti F, Kokkinn MJ, Williams WD (1992) A standard table for predicting equilibrium dissolved oxygen concentrations in salt lakes dominated by sodium chloride. Int J Salt Lake Res 1:1-6

> Walsby AE (1980) A square bacterium. Nature 283:69-71

- Warkentin M, Freese HM, Karsten U, Schumann R (2007) New and fast method to quantify plankton community respiration by optical oxygen sensor spots. Appl Environ Microbiol 73:6722-6729

Submitted: November 26, 2008; Accepted: February 12, 2009 Proofs received from author(s): May 13, 2009 